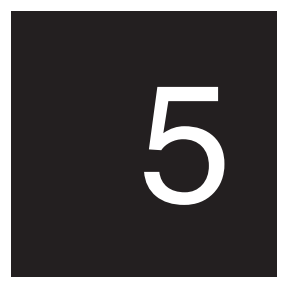

\title{
Governance, development and leadership in Polynesia: a microstudy from Samoa
}

\section{Malama Meleisea}

One of the reasons that governance has become a fashionable topic for research is because it is now held by agencies such as the World Bank that successful 'development' is contingent on a certain manner of government. I am using the word development in the sense it is used by international agencies to refer to things like economic growth and rising standards of living which can be measured by statistics for education, health, life expectancy and so on. It is now increasingly argued that the kind of government that is needed to produce such development is one that operates in a transparent manner, so its actions are known to its citizens; in other words, government which is accountable for its actions. One aspect of this discussion is that values about governance are rooted in culture, and that not all cultures value the kind of openness and acceptance of individual rights that Western thinkers have argued to be the basis of human development. There is debate about whether the kind of cultural values which underlie modernisation in the West are really necessary for a country to be economically successful. For example, an interesting new book by Huntington (1997) argues that we are in the early stages of new global conflict over different pathways, with 'development' values competing between cultural regions.

Twenty years ago, we used to talk about the particular amalgam of political, economic and cultural features of our region as the 'Pacific 
Way'. However this has become such a cliché that we are now embarrassed to use the term to refer to the set of attitudes and values that were supposed to characterise our region. Professor Hau' ofa demystified such slogans by pointing out that they were dreamt up by élites with more in common with each other than with the ordinary people of their countries. However lately it has again become popular for the Pacific to be considered in this collective way. The recent World Bank studies, and the Pacific 2010 series produced by the National Development Studies Centre at the Australian National University have all pointed out the 'paradox' of the Pacific islands-that despite high levels of aid, populations are growing but not economies. Predicting that aid is drying up, these books point out that without economic growth there cannot be continuing improvements in education, health, and public infrastructure-because there will be no money to pay for these things (World Bank 1993, Cole 1993).

The present recipe for solving this problem is the application of policy reforms, usually at the instigation of the International Monetary Fund, the Asian Development Bank and other donors. This is usually only done when the country has reached a financial crisis and can no longer pay its wages and bills, let alone its overseas debts. In 1997 it was the Solomon Islands. In 1998 the most celebrated victim was the Cook Islands, a few years ago Samoa was in the same situation and some gloomy forecasters say that Fiji will be next. In recent years Pacific island countries only seem to get into the news because the leaders of one of our countries have been caught with their hands in the till. There has been misappropriation of public money in Samoa and Fiji, involving politicians and heads of government agencies. There is an on-going saga of corruption in the forest industry in Solomon Islands and Papua New Guinea. The army of Vanuatu recently kidnapped their president to force the Government to pay wages owed to them. Finally, as a lesson to locals who are too critical, there was the recent imprisonment of outspoken journalists in Tonga, and the charges of sedition against members of the opposition in Samoa for criticising government policy.

In a recent analysis of government and tradition in the Pacific islands, Stephanie Lawson concludes that there is a lingering 'traditional' element in all this (Lawson 1996). To understand the problem, we need look no further than Max Weber's classic analysis. The different bases of legitimacy which characterise 'traditional' and 'rational legal' forms of political authority are that the latter is based 
on formal laws and regulations, while the former is based on hereditary privileges attached to leaders. In the discussion of the 'politics of tradition' anthropologists have been interested in the way in which Pacific leaders and authority in Pacific societies have invoked culture and tradition as a means of justifying their behaviour, and have recognised that the politics of tradition has some of its roots in colonial intervention. For example, institutions which we have been asked to revere because of their traditional nature such as the Samoan matai system, the Tongan Monarchy or the Fijian Great Council of Chiefs, were all colonial compromises between traditional and modern forms of government. The modern arbitrator of Samoan custom, the Land and Titles Court, was founded to enable the central government to become involved in questions of chiefly succession. The German administration hoped to do away with the whole basis of chiefly authority, and invented the Land and Titles Court. All these things happened such a long time ago that people today see them as features which make their society unique and different from others. Thus most Tongans feel some sort of pride in their King, Samoans feel that their fa'amatai is what makes them a particular sort of people, and so on.

When Samoa became independent in 1962 a constitution was adopted which, it was hoped, would give us the best of Samoan and Western political institutions. It gave us two systems of legitimacy to draw on. One was the Samoan system of chiefly authority, based on the idea that titleholders would represent the interests of the extended families who gave them their titles. The other was more vaguely defined as a set of Western liberal principles such as individual rights, religious freedom, equality under law and so on. The contradictions between these two sets of principles was not really a problem in 1962 because most people lived in villages in a semi-subsistence economy, and migration and influences from the outside world had minimal impacts on most of us. Since then we have experienced changes which have made us among the most 'globalised' of people. During the 1970s and 1980s about one third of our population moved overseas, forming communities in the United States, New Zealand and Australia. In a period of 20 years we became, in effect, a nation without geographic boundaries.

Inevitably this process has had an impact on our political system because the economic impact of emigration was towards individualism. The two village censuses carried out by my wife, Dr Penelope Schoeffel, in 1976 and 1986 showed that while the population had not grown, 
there had been a sharp increase in the number of households. The great increase in the practice of splitting titles between multiple incumbents during this period, also reflected the break-up of families into smaller units. Prior to the elections of 1991, and following a national referendum, the government amended the Electoral Act to give universal suffrage to all people over 21 (previously only registered matai voted). But at the same time, in a sort of trade-off for this democratic concession, parliament voted for an extension of the parliamentary term from three to five years, and passed an act giving greater powers to village councils to enact and enforce village by-laws. These changes were accompanied by a great deal of rhetoric about the transition to democracy. They came about under a ruling party calling itself the 'The Human Rights Protection Party'.

Despite this supposed transition to a more democratic system of government, it is commonly believed that there is high-level corruption in Samoa. Until 1994, it was persistently rumoured that certain ministers and heads of departments had formed companies headed by close relatives to which they were awarding uncontested government contracts involving very large sums of public money. When a local newspaper cautiously alluded to these goings on, our Prime Minister stood up in Parliament and compared the local press to 'a lot of little stones rolling in the gutter'. We must recognise that rumour-mongering has been a popular local pastime for a long time, but these rumours were given more substance in 1994 when the Auditor General presented his report to parliament. This document gave details of massive official corruption. While nobody was surprised at the contents of his report, many were surprised and relieved that the Auditor General had found the courage to speak out. Samoa is a small country, with few senior jobs, so outspokenness is bad for one's career. In response to these revelations the Government appointed a commission of enquiry. After many months had passed, the findings of the Commission were presented in a document so strangely written that nobody could really understand its contents.

But one thing stood out. While the Commission's report vaguely acknowledged that most of the Auditor General's allegations had substance, its main finding was that he was at fault for exceeding his mandate. In short, the Auditor General was suspended from his position and, after two years, had not been reinstated. In the latest election which was held this year, the ruling Human Rights Protection Party was returned to office. Although it did not have a clear majority, 
it was able to persuade a number of independents to help form a government. Several parliamentarians named in the Auditor General's report have been re-elected and re-appointed to cabinet. Similarly, many of the heads of departments implicated still hold their positions.

Why has this sort of public dishonour caused so little concern in my country? I suggest that the problems are linked to the fact that we are living in two worlds, a situation which is breeding a kind of moral confusion. It is not that there are contradictions between new and old principles, but that these two sets of principles can be selectively invoked to justify our actions as it suits us. For example, our cultural principles disapprove of questioning, challenging or criticising our chiefs, and by extension our government. At the same time, we learn that in today's world, prestige and power come from the possession of money, and to obtain it we must be determined individualists.

\section{The case of the two-storey house}

The village that I grew up in has a population of between two and three hundred people. It is governed by a council of matai who are the holders of about 21 village titles. Some of the village titles are held by more than one person, so altogether there are about thirty matai. Of these, two titles are the most senior in ranking, both in the village and in the surrounding district. When I was growing up there, these two titles were each held by one person, but now both of them have been split, so there are several holders of each.

My story concerns two holders of these senior titles, Va'a and Samoa. They are both middle-aged men with adult children living away from the village in town or overseas. One has a small but not very successful store run by his wife, and until recently he earned his living as a Member of Parliament. The other is a subsistence farmer who lived for most of his life in a small fale Samoa, but who recently, with the help of his children overseas, built himself a small modern style house (fale palagi).

About two years ago these two chiefs filed a petition in the Lands and Titles Court to stop a junior chief called Solomona from completing his two-storey house which he had built beside the main road behind the village. The Lands and Titles Court, in response to the petition of the two high chiefs, sent an order notifying Solomona about the objection, and asking him to stop building the house. Solomona obeyed the order and continues to live in rooms behind his shop. After two years the court case is still pending and the house still stands half 
completed. It is quite common in Samoan custom for titles to carry with them certain privileges, especially if the titles are of high rank. High ranking titles usually carry special rights to be addressed in certain ways, to confer certain titles, to wear a headdress (tuiga) on certain occasions, to build a house in a certain location, and so on. It is not uncommon for modern versions of particular privileges to be added to titles as well. For example it is common for important titles to carry with them the right to be served tea out of a separate teapot while everyone else drinks from a common pot.

Solomona, the owner of the unfinished two-storey house, is in his late thirties and is regarded as one of the most successful businessmen in our district. Unlike most other well-off people in Samoa, he did not earn his capital by working overseas. He began about twelve years ago with a small store on his family land in the village. A few years later he took advantage of a government fisheries development project, which enabled him to buy a fishing boat. Then, assisted by his younger brothers in running the fishing boat, he built up a successful enterprise, fishing twice a day and selling the catch at the Apia market. After a year he bought a second boat and recently bought a third. With his fishing income, he extended his store, bought a truck and a small van, and also a small herd of cattle which he grazed on family coconut land. He soon dominated trading in the village, and became one of the leading traders in the district. The only other store in the village belonged to one of the high chiefs, Va'a.

Determined to expand his business, he abandoned the old store and relocated it on the main road where he was able to attract more customers from the traffic passing through the district. He also started a small banana plantation nearby, and a year later began work on his two-storey house. The land to which he relocated is regarded as tuamaota, referring to the fact that it is at the back of the village, and distinguishing it from the important sites round the malae. The site has no chiefly connotations; indeed Solomona's house is being built on the site once occupied by the village pig sty.

Solomona has always lived in the village, which is unusual since the emigration rate is very high. He went to primary, intermediate and junior high school there and then became a subsistence farmer and fisherman, gradually accumulating the means to start his businesses. He left school after Form 5. People say he is like his mother's late father, who was known in the village for his hard work and throughout the district as a master fisherman (tautai). Solomona's 
grandfather was also the first Samoan in the district to own and operate a bus, which was not only very useful for the village, but very much admired. So, in the 1960s, when Solomona's grandfather was very old, one of the previous holders of the two high titles of the village split the title he held, and bestowed the title on Solomona's grandfather. He did this to reward him for his service and achievement. However, because the old man's genealogical links to the title were somewhat tenuous, at the time this was a very controversial action. Of the two chiefs opposing Solomona's twostorey house, one came from a very well known family, but the other had acquired his high title in a manner that was just a tenuous as that of Solomona's grandfather.

There have been more dramatic cases of chiefs resisting innovation and change in their villages than my story of Solomona's two-storey house. For example in a case which occurred in Falelatai in 1986, a village entrepreneur was attacked, his business boycotted, and he was eventually expelled from the village because he disobeyed its village conventions. At one point his fellow matai were prepared to sentence him to an ancient punishment which involved trussing him to a pole like a pig and cooking him on the fire. Fortunately the village pastor intervened to save him. Another village entrepreneur in Fagaloa was less fortunate. He was shot dead, after which his house, store and truck were burned by village youths acting on the order of the fono. The man they executed defied the evening curfew for prayers required by the village, and had joined the cricket team of a rival village.

Both these cases, as I have said, involved small business operators who had accumulated the capital for their businesses from many years of working in New Zealand. They returned and tried to do things differently, challenging the rules of their villages. Typically the agents of change have been returning emigrants who have wanted to do things differently, but Solomona was different. Although his case involves the same clash between conflicting constitutional principles and customary and individual rights, Solomona never left the village. His behaviour was correct by customary principles; as a young man he worked for the village youth group, and when he got his title he became a member of the fono. He is a dutiful member of the church. The unconventional aspect is that he has more money and status, in the modern sense, than the high chiefs of the village. Perhaps we could say that this case illustrates an uncomfortable disjunction between class and rank. 
As stated above, since the 1960s there has been an increasing trend toward economic individuality in most villages, which has been accelerated by new farming technologies which reduce labour requirements, by emigration and remittances, urbanisation and changing values, and a greater emphasis on nuclear families as distinct economic units. This has tended to weaken the solidarity of descent groups and extended families, and it has contributed to fragmentation where rival branches of families are contesting and splitting titles and the assets attached to them. Allegiance and service to chiefs has become more tokenistic as functional economic and political interdependencies have been increasingly weakened by the emergence of new economic and political institutions. At the same time, high-ranking chiefs continue to invoke traditional privilege to try to prevent those who have achieved status through the agency of the modern market economy from overshadowing them.

While important chiefs continue to demand their traditional rights and privileges, there are signs all around us in Samoa today that they are no longer willing to carry out their communal responsibilities. For example, during most of this century our villages have had a particular tradition of self-reliance, in which the village builds and maintains its own schools, and groups of villages-working through district councils of representatives-have built and maintained their own health centres. Villages even provided the food for teachers and doctors working at village levels, to supplement their salaries (although this practice was discontinued when public service salaries were increased in the early 1960s).

Although village and district leaders are still expected to organise the maintenance of public facilities, the junior high school in my district has been gradually deteriorating since the early 1970s, and about six years ago the leading chiefs of each village decided to go on a fundraising expedition to New Zealand to pay for the renovation of the school-but when the fundraising group returned no work was ever carried out. The money vanished and remains unaccounted for to this day. There are many other examples of public funds disappearing into the pockets of local leaders in similar circumstances, even where the government provides funds for public works in villages. In recent years, under the provisions that give greater powers to local village councils, the government allocated funds to each village council for the maintenance of local plantation access roads. The amount is determined by the number of roads per village, with the average grant 
for each road being WS $\$ 4000$. In one well known incident recentlyalthough this was not in my village- the village council donated almost the entire road maintenance grant for the year to a new conference centre being built by the Catholic church in another district. Why? Because this village is associated with one of the paramount chiefs of Samoa, and the paramount chief in question asked the village council to raise a donation to be given in his name. Rather than go to the trouble of raising the funds in the usual manner, the village council decided to allocate most of their road maintenance grant for the year.

My village has only one access road and it has been the practice in recent years for the road maintenance money to be divided among the three high ranking ali'i and the pastors, with far smaller amounts to the other village matai. Not only is there no work done on the access road, the purpose of which is to assist agricultural production, but the money seems to be spent on card games, beer and food, with little (if any) of the money reaching the youth, women and children of the village.

The district health centre was once maintained by a consortium of village women's committees who raised funds, took it in turns to provide voluntary labour to help the nurses and doctor, and to weed and clean the compound. Today the health centre is deteriorating with minimal community support because the leading families have pickup trucks and are able to go to town to obtain medical care.

We hear much today about the environmental fragility of the Pacific islands, and the problem of shoreline erosion. This has always been a problem in my village, and in the past each household prevented erosion of the sea on the foreshore near their houses, by collecting large rocks and constructing breakwaters. However today it is left to the central government to address this problem, and the central government takes the problem to international aid donors. The high ranking chiefs try to get the government to pay for a sea wall with aid to stop erosion, but families did this themselves in the old days.

What I find interesting — and sad—about the leadership decline that I have been talking about is how cynical rural people have become. One way in which people have responded is to become more individualistic, but individualism only works well for those who are reasonably prosperous. Families with few material possessions were major beneficiaries of community provision of services in the past and 
it is obvious that the gap between the haves and the have-nots is increasing in rural areas as well as in town. Village matai control the churches of Samoa as well as local government, and have the power to fine people who show their cynicism by not attending church. While the Village Fono Act of 1991 was heralded as a move to reinforce and strengthen rural self reliance, it has in fact formalised the power of matai and local hierarchies. The Act allows matai to force compliance with their dictates through the means of fines or even expulsion from the village. Increasingly rural people see $f a^{\prime}$ asamoa as another word for oppression.

\section{Conclusion}

My story of Solomona and his two-storey house is a parable of the situation in contemporary Samoa. It illustrates my contention that the political rhetoric about rural development and self-reliance which accompanied the introduction of universal suffrage in 1991 has little substance. These changes have in fact disguised the potential for the abuse of chiefly power. Although we may now elect our Parliament, the matai who run the country have given themselves a five year term of office, and increased powers at village level. There are few checks on the abuse of rank privilege, which allow leaders to invoke their rank privileges to suppress dissent or competition.

I do not accept that this has always been a feature of our political system. My earlier example of Solomona's grandfather was just one of many that I can give to show how achievement was recognised and rewarded. I think what is occurring is symptomatic of a moral vacuum which has arisen among a people who are trying to live in two worlds. We have two concurrent sets of social and political values, either of which may be appealed to as it suits us.

In Western Polynesia, we are no longer small nations of people belonging to a few small islands. Today we are nations of people without borders. We extend, as Hau' ofa has pointed out, across seas; operating, as Bertam and Watters (1985:511) have put it, as transnational corporations of kin. We now draw unconscious distinctions between society and the state. People are both citizens of the state and members of society, but the rules of being a citizen and a member of society are not always the same. Take the case of the two chiefs in my story. They were attempting to defend traditional principles of society and the rank order of their village, even though, paradoxically, they were appealing to an agency of the state, in the 
form of the Lands and Titles Court. However, Solomona might equally well appeal to the state to uphold his rights as a citizen and his rights as an individual to build the house of his choice. The outcome of my story is still not known.

The idea of the state, of the common good on a national scale, was introduced at independence. Before that, the state was seen as the possession of the colonial power. Government was what they controlled, and families and villages were what we controlled. Before we had time to develop a consensus about what it was to be a citizen, as distinct to being the member of an extended family or a village polity, there was mass emigration. This led to the further objectification, for want of a better word, of Samoan-ness, to defend against outsiders. Emigration increased this process as we formed little islands of Samoan-ness in seas of palagi society around the world. Thus the petition of the two chiefs against Solomona's house is based on the convention that no one in the village- other than the holders of its paramount titles-may build a two-storey house. Since none of the high chiefs had ever owned a two-storey house, in effect the rule is that no one in the village of lower rank may build a house of greater height than the houses of its high chiefs. Two-storey houses of course are not 'traditional' but they have been common in Samoa for the past century and are generally seen as being more prestigious than onestorey houses. In the past, Samoan houses displayed the rank of the occupant by the number if tiers (or the height) of the stone foundations (paepae) on which the house was built. Therefore the modern status equivalent to a house built on a high foundation would be a two-storey house, and thus this indicator of rank was reserved for the high chiefs of the village. Local by-laws to protect the dignity of the high chiefs are quite common. For example, in my mother's village in the 1970s, only chiefs were allowed to use umbrellas, carry brief cases, or to use fans in church.

In the case of Solomona's two-storey house, the village council of matai, the fono, did not take action against him. It could have ordered him to stop building his house, or it could have fined him, as is usually done when someone breaks a village convention. It was noteworthy that the two high chiefs did not appeal to the fono, but took their case against Solomona to the Land and Titles Court themselves and in so doing they were shifting the grounds for complaint. If Solomona was in breach of local convention, then the matter should have been for the fono to adjudicate, but by taking the 
case to the Land and Titles Court, the two high chiefs were, in effect, asserting that the building of a two-storey house is a traditional perquisite attached to the defence of those elements of culture that have come to be seen as a virtue. The questioning of them is seen to be an attack on our integrity as a people. For those of us who live in Samoa, this has retarded the evolution of a sense of citizenship, with the ill-effects on governance that I have discussed previously.

\section{References}

Bertram, I.G. and Watters, R.F., 1985. 'The MIRAB economy in South Pacific microstates', Pacific Viewpoint, 26(3):497-519.

Cole, R. (ed.), 1993. Pacific 2010: challenging the future, National Centre for Development Studies, The Australian National University, Canberra.

Huntington, S.P., 1997. The Clash of Cultures and the Restructuring of the World Order, Simon and Schuster, New York.

Lawson, S., 1996. Tradition Versus Democracy in the South Pacific: Fiji, Tonga and Western Samoa, Cambridge University Press, Cambridge.

World Bank, 1993. Pacific Island Economies: toward efficient and sustainable growth, World Bank, Washington DC. 